\title{
Article \\ Shallow Hydrothermal Vent Bacteria and Their Secondary Metabolites with a Particular Focus on Bacillus
}

\author{
Revathi Gurunathan ${ }^{1,2}$, Arthur James Rathinam ${ }^{3, *}$, Jiang-Shiou Hwang ${ }^{4,5,6, *(\mathbb{D})}$ and Hans-Uwe Dahms ${ }^{2,7,8, *(D)}$ \\ 1 Department of Medicinal and Applied Chemistry, Kaohsiung Medical University, Kaohsiung 80708, Taiwan; \\ gururevati@gmail.com \\ 2 Department of Biomedical Science and Environmental Biology, Kaohsiung Medical University, \\ Kaohsiung 80708, Taiwan \\ 3 Department of Marine Science, Bharathidasan University, Tiruchirapalli 620024, India \\ 4 Institute of Marine Biology, National Taiwan Ocean University, Keelung 20224, Taiwan \\ 5 Center of Excellence for Ocean Engineering, National Taiwan Ocean University, Keelung 20224, Taiwan \\ 6 Center of Excellence for the Oceans, National Taiwan Ocean University, Keelung 20224, Taiwan \\ 7 Research Center for Environmental Medicine, Kaohsiung Medical University, Kaohsiung 80708, Taiwan \\ 8 Department of Marine Biotechnology and Resources, National Sun Yat-Sen University, \\ Kaohsiung 80424, Taiwan \\ * Correspondence: james.msbdu@gmail.com (A.J.R.); jshwang@ntou.edu.tw (J.-S.H.); \\ hansd@kmu.edu.tw (H.-U.D.)
}

Citation: Gurunathan, R.;

Rathinam, A.J.; Hwang, J.-S.;

Dahms, H.-U. Shallow Hydrothermal Vent Bacteria and Their Secondary Metabolites with a Particular Focus on Bacillus. Mar. Drugs 2021, 19, 681. https://doi.org/10.3390/md19120681

Academic Editor: Ipek Kurtboke

Received: 28 September 2021

Accepted: 26 November 2021

Published: 29 November 2021

Publisher's Note: MDPI stays neutral with regard to jurisdictional claims in published maps and institutional affiliations.

Copyright: (c) 2021 by the authors. Licensee MDPI, Basel, Switzerland. This article is an open access article distributed under the terms and conditions of the Creative Commons Attribution (CC BY) license (https:// creativecommons.org/licenses/by/ $4.0 /)$

\begin{abstract}
Extreme environments are hostile for most organisms, but such habitats represent suitable settings to be inhabited by specialized microorganisms. A marine shallow-water hydrothermal vent field is located offshore in northeast Taiwan, near the shallow shore of the southeast of Kueishantao Island $\left(121^{\circ} 55^{\prime} \mathrm{E}, 24^{\circ} 50^{\prime} \mathrm{N}\right)$. Research on extremophilic microorganisms makes use of the biotechnological potential associated with such microorganisms and their cellular products. With the notion that extremophiles are capable of surviving in extreme environments, it is assumed that their metabolites are adapted to function optimally under such conditions. As extremophiles, they need specific culture conditions, and only a fraction of species from the original samples are recovered in culture. We used different non-selective and selective media to isolate bacterial species associated with the hydrothermal vent crab Xenograpsus testudinatus and the sediments of its habitat. The highest number of colonies was obtained from Zobell marine agar plates with an overall number of 29 genetically distinct isolates. 16S RNA gene sequencing using the Sanger sequencing method revealed that most of the bacterial species belonged to the phylum Firmicutes and the class Bacilli. The present study indicates that hydrothermal vent bacteria and their secondary metabolites may play an important role for the reconstruction of the evolutionary history of the phylum Procaryota.
\end{abstract}

Keywords: hydrothermal vent (HV); bacteria; extremophile; bioactive substance; molecular phylogeny

\section{Introduction}

Marine and terrestrial environments that are extremely hot are habitats for only a few living organisms. However, such extreme environments present suitable habitats for specialized microorganisms called extremophiles [1]. Many bacteria and archaea are reported from such extremely harsh environments, having the potential to tolerate a wide range of temperatures and $\mathrm{pH}$ or high concentrations of salt [2]. Such microbes are called extremophiles and can be further classified on the basis of their specific needs, for example, as thermophiles (adapted to higher temperatures), psychrophilic (adapted to cold temperatures) and halophiles (adapted to high salinities) $[3,4]$. The interest in studying microorganisms from extreme sites is exemplified by Thomas Brock's extraordinary discovery of the hot springs of Yellowstone National Park in the 1960s [5,6]. Subsequently, several other thermophilic sites were sampled for thermophilic microorganisms on this planet $[7,8]$. Kueishan Island, later called Kueishantao (KST), is an island in the southern 
East China Sea, which erupted about 7000 years ago and is located about $10 \mathrm{~km}$ from the Yilan County coast, Taiwan $\left(121^{\circ} 55^{\prime} \mathrm{E}, 24^{\circ} 50^{\prime} \mathrm{N}\right)[2,9,10]$. It is located at an intersection between the Okinawa Trough and the Philippine Plate. The eastern sea near KST is a shallow, submarine hydrothermally active area [11-13] (Figure 1). About 50 individually discernable hydrothermal vents at depths of 5-30 m were discovered in eastern KST subtidal regions over an area of $\sim 0.5 \mathrm{~km}^{2}$ early in the last century [14]. The constant magmatic activity underneath the area of KST is due to the westward expansion of the Okinawa Trough. The KST vent fluids undergo drastic temperature changes that either fall in the range of $78-116{ }^{\circ} \mathrm{C}$ or vary down to $30-65^{\circ} \mathrm{C}$ [14-17].

Such shallow-water hydrothermal vents provide few nutrients and, therefore, have an oligotrophic and toxic environment as they are situated near actively bustling coastal or submarine volcanoes [18]. The only multicellular organism found in this region, also considered one of the vent-endemic species living at depths down to $250 \mathrm{~m}$, is the crab Xenograpsus testudinatus. This crab predominates in these vents and is able to withstand the sulfur-rich/highly acidic hydrothermal vents with $\mathrm{pH}$ values ranging from 1.75 to 4.6 . Some recent studies have reported the food requirements of $X$. testudinatus, but only a few reports have focused on the microbes associated with X. testudinatus $[18,19]$.

Extremozymes from extremophilic bacteria may have substantial industrial applications as biocatalysts, being functional under harsh treatments, where most of the common enzymes lose their activity and are denatured due to high temperatures or extremes in $\mathrm{pH}$ [20]. A wide spectrum of unique properties make them useful in various industrial and other applications [21]. Advanced techniques and methods by which to culture such microorganisms and increase the yield of the production of biomass, enzymes and other biomolecules of interest have been developed [22]. The studies reported so far also support this, and the microorganisms that can withstand harsh and extreme conditions are, therefore, of great interest $[23,24]$.

Hydrothermal vent marine bacteria are difficult to isolate and cultivate because of their particular culture requirements. However, different culture techniques can be optimized in laboratory conditions that make their successful cultivation possible. Such knowledge will also enhance our understanding of the evolution of hydrothermal vent microbiota and their secondary metabolites in this unique extreme environment [25].

The aim of this article was to identify bacterial systematic and metabolic diversity from shallow-water hydrothermal vents. We focus here on media optimization for the isolation of a maximum number of bacterial colonies in order to study their diversity and phylogenetic relationship and the diversity of bioactive compounds. This study focuses on extremophiles since these microbes are expected to tolerate a wide range of, e.g., temperatures, pressure, $\mathrm{pH}$ and elevated concentrations of heavy metals. This provides the expectation of harvesting unique secondary metabolites that may also protect the bacteria from extreme physicochemical factors and provide new pathways for energy acquisition.

\section{Results and Discussion}

\subsection{Bacterial Diversity Studies}

Using standard cultivation methods, a maximum number of colonies were isolated using Zobell marine agar and nutrient agar with $\mathrm{NaCl}$ as selective media (Table 1). Only a few bacterial colonies can grow on TSA and sea water. Distinct colonies were identified by different morphology and color. Solid bacteriological culture media are mostly used for the isolation and enumeration of bacteria from environmental samples, applying the diluting method where the original bacterial suspension is diluted to the desired folds and a small inoculum is spread over the surface of a solidified medium. The ability of a bacterium to grow and yet fail to show up as a CFU through the plate or broth culture method leads to "viable but non-culturable" (VBNC) bacteria [26]. The "unculturable state" discussed here is tentatively defined as the physiological condition in which marine bacteria do not grow, e.g., as colonies (CFUs) on agar plates [27]. The VNC concept has a broad impact for the majority of research aspects in environmental microbiology [28]. Some of the bacterial 
cells retrieved from environmental samples may simply die during the cultivation process. Pasotti et al. [29] reported that some of the lethal effects are associated with physical or chemical agents, which lead to a process of "self-destruction" by the cells themselves.

Table 1. Colony forming units of bacterial colonies obtained from different media.

\begin{tabular}{ccc}
\hline S. No. & Media & No. of Different CFUs Obtained \\
\hline 1 & Nutrient media supplemented with $\mathrm{NaCl}$ & 7 \\
\hline 2 & Nutrient media without $\mathrm{NaCl}$ & 12 \\
\hline 3 & Tryptic soy media & 8 \\
\hline 4 & Zobell marine media & 18 \\
\hline 5 & Seawater complete & 2 \\
\hline 6 & Casamino acid seawater & 2 \\
\hline
\end{tabular}

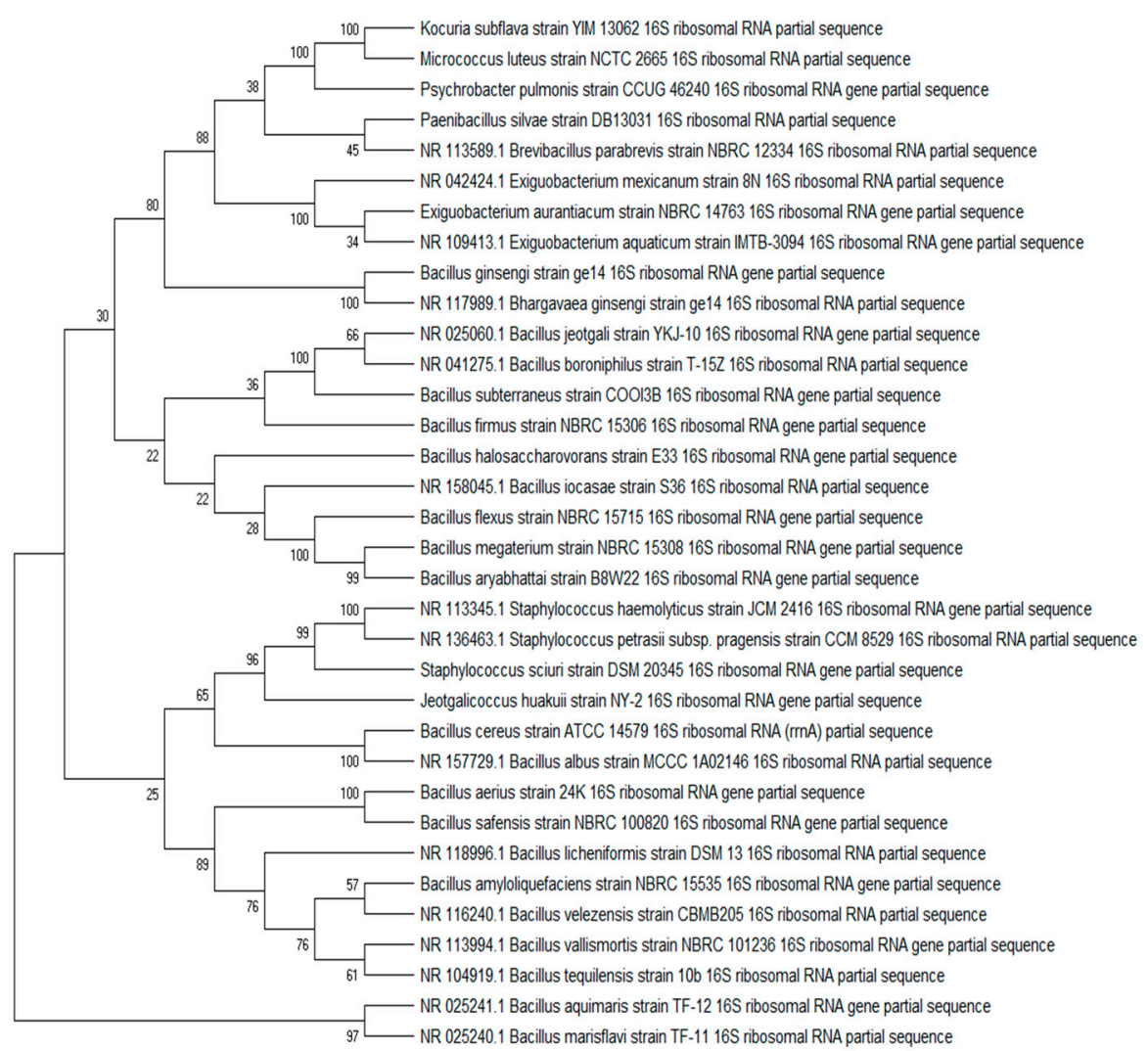

Figure 1. Phylogenetic tree constructed from hydrothermal vent bacteria isolates using MEGA $X$ software with 100 bootstrap values.

The sequencing results revealed that most of the bacterial species isolated by $\mathrm{Gu}-$ runathan et al. (2021) belonged to the phylum Firmicutes. From the phylum Proteobacteria, one isolate was identified as Psychrobacter pulmonis belonging to the phylum Proteobacteria, order Pseudomonadales. From the phylum Actinobacteria, two bacterial colonies were isolated. One bacterium was identified as Kocuria subflava, belonging to the family Micrococcaceae. The other isolate was identified as Micrococcus belonging to the family Micrococcaceae and the species M. luteus. The predominant bacteria belonged to the phylum Firmicutes, family Bacillaceae. The different isolated species of Bacillus were B. aerius, B. aryabhattai, B. ginseng, B. aquimaris, B. iocasae, B. firmus, B. marisflavis, B. safensis, B. subterraneus, Micrococcus luteus, Bacillus megaterium, Bacillus cereus, B. vallismortis, B. licheniformis, B. jeotgali, Bacillus boroniphilus, B. halasaccharovorans, Bacillus flexus, Bacillus 
velezensis, B. albus, B. tequilensis, B. paramycoides and Brevibacillus parabrevis. Five bacterial isolates belonged to different genera and species of the taxon Bacillaceae, i.e., Paenibacillus silvae, Exiguobacterium aquaticum, Exiguobacterium aurantiacum, Staphylococcus sciuri and Jeotgalicoccus huakuii. The phylogenetic tree was built using BLAST and MEGA software version $X$ (Figure 1). The sampling source provided a difference since the bacterial colonies isolated from different samples were different. A maximum of colonies were isolated from the HV crab's carapace and its ambient sediments (Figure 2).

Related to our studies was the bacterial diversity of hot springs from Araró, Mexico, identified by $16 \mathrm{~S}$ rDNA sequencing [30]. Seventeen bacteria were isolated and identified from both hot springs, which included bacteria from the phylum Firmicutes, Proteobacteria and Actinobacteria, and Firmicutes strains from Paenibacillus, Bacillus and Exiguobacterium (76\%), Pseudomonas and Aeromonas (18\%) from (Proteobacteria) and 6\% of Actinobacteria with the genus Microbacterium. The $16 \mathrm{~S}$ rDNA sequences indicated Bacillus as the dominant group including Bacillus subtilis, B. licheniformis, B. pumilus and B. cereus. The most frequently occurring species were Bacillus amyloliquefaciens, Aeromonas hydrophila, Bacillus vietnamensis, Bacillus megaterium, Bacillus boroniphilus and Exiguobacterium profundum. The bacterial species appearing in only one of the samples were Exiguobacterium sibiricum, Bacillus oceanisediminis, Paenibacillus favisporus, Paenibacillus pabuli, Pseudomonas psychrotolerans, Pseudomonas stutzeri and Microbacterium oleivorans [30]. The results reported by Prieto et al. [30] had similar findings to those of our study. The species percentage as reported by the above authors was similar to that of our studies where Bacillus was dominant and only one species of Paenibacillus was found. The microbial diversity studied by Cui et al. [31] in the South China Sea from two cold seep systems in gas-hydrate-bearing sediments showed a relatively low abundance of Planctomycetes and Firmicutes bacteria. When the authors applied the Mann-Whitney U test, they found among the phylum Firmicutes Bacilli and Clostridia, Bacteroidia from the phylum Bacteroidetes, Acidobacteria and Cyanobacteria in abundance in the non-gas hydrate zone [31]. The microbial isolates studied by Kumar et al. [32] showed diversity in subsurface seawaters from the western coastal ecosystem of the Arabian Sea, India. The bacterial communities were dominated here by Proteobacteria, followed by Firmicutes [32]. Representatives of Bacillus, known for their tolerance, were predominant in most extreme environments. The bacteria in our study were isolated from sulfur-rich hydrothermal vents. Meyer-Dombard et al. [33] studied the microbial diversity at an arsenic- and iron-rich vent with biogeochemical cycling carried out using bacteria at Tutum Bay from Papua in New Guinea. The bacterial isolates were classified as alpha- and beta-Proteobacteria, and the genera were Thermus and Pyrobaculum [33]. In the bacterial phylogenetic study of Shinde et al. [34], 49 newly generated sequences within four bacterial phyla from tarballs were collected from Betul, Goa, India, which included Proteobacteria (38 species), Gammaproteobacteria (31 species), Alphaproteobacteria (7 species), Actinobacteria (6 species), Firmicutes (4 species) and Bacteroidetes (1 species). Among the Actinobacteria, the species belonged to Cellulomonas (three species) and Brevibacterium (two species); from the Firmicutes, Bhargavaea (three species); and only one species was found from Bacillus (one species). In a study from southeastern Arabian Sea sediments, the dominant genera were Clostridium and Bacillus belonging to the phylum Firmicutes [35]. The other genera were Lactobacillus, Enterococcus, Oscillospira and Staphylococcus [35]. Isolates from the Wadden Sea (North Sea) revealed that $16 \%$ of the isolates were affiliated to the Bacillus/Clostridium group, and $10 \%$ belonged to the phylum Actinobacteria. The presence of a relatively high number of Gram-positive bacteria may indicate the specific characteristics of the Wadden Sea environment [36].

Both abundance and bacterial diversity are generally substantially underestimated by CFU counts. The present study substantiated this notion by identifying 31 different bacterial strains through a comparison of $16 \mathrm{~S}$ rRNA gene sequences from various microbial isolates from hydrothermal vent sediments and the invertebrate crab Xenograpsus testudinatus. 


\subsection{Characteristics of the Isolated Bacterial Colonies}

Culture characteristics were studied for isolated bacterial colonies. The morphologies and phenotypes were observed. The results showed that most of the bacteria belonging to the genus Bacillus have white colonies, such as Bacillus albus, and cream-colored colonies, such as Bacillus flexus, although a few species showed pigmented colonies. The color of the colonies varied; in Bacillus tequilensis, the colonies appeared as yellow; the species Micrococcus luteus appeared as bright yellow; and the colonies of Bacillus jeotgali and Brevibacillus parabrevis appeared as pale yellow. Some colonies had an orange color, such as Exiguobacterium mexicanum and Exiguobacterium aurantiacum. Apart from the color differences, some colonies appeared glossy, such as Paenibacillus silvae and Bacillus firmus; colonies of Bacillus amyloliquefaciens showed highly raised, mucous filled colonies. Bacillus licheniformis showed branched, hair-like, irregular morphology, and Bacillus cereus showed branched, fuzzy, irregular edges (Table 2).

Table 2. Bacterial phenotypes studied here and their optimal temperature and media.

\begin{tabular}{|c|c|c|c|c|}
\hline No. & Bacteria & Optimal Media & Temperature $\left({ }^{\circ} \mathrm{C}\right)$ & Phenotype \\
\hline 1 & Bacillus aerius & Lb without and with $\mathrm{NaCl}, \mathrm{NA}, \mathrm{ZMA}$ & $30-37$ & White, irregular, raised \\
\hline 2 & Staphylococcus haemolyticus & NA, LB, TSA & 37 & Light yellow \\
\hline 3 & Bacillus aryabhattai & MA, Nutrient and $\mathrm{Lb}$ with $\mathrm{NaCl}$ & 37 & Opaque, white, raised, irregular \\
\hline 4 & Bacillus ginsengi & NA, LB, TSA & 37 & Light yellow \\
\hline 5 & Bacillus aquimaris & MA, Nutrient and $\mathrm{Lb}$ with $\mathrm{NaCl}$ & $30-37,42$ & Yellow pale, circular to slightly irregular and raised \\
\hline 6 & Bacillus iocasae & Nutrient agar with $2 \% \mathrm{NaCl}$, Zobell marine agar & $32-37$ & Off-white \\
\hline 7 & Bacillus firmus & TSA, LB, NB with $\mathrm{NaCl}, \mathrm{MA}$ & 37 & Shiny, circular, semi-transparent, flat colonies \\
\hline 8 & Kocuria subflava & MA & 37 & Yellow colonies \\
\hline 9 & Bacillus marisflavis & Marine agar, $\mathrm{LB}$ with and without $\mathrm{NaCl}$ & 27 & Pale yellow, smooth, circular to slightly irregular \\
\hline 10 & Bacillus safensis & TSA, with and without $\mathrm{NaCl}$ & $32-37,42$ & Irregular margins, off-white/cream \\
\hline 11 & Exiguobacterium aurantiacum & MA & $27-37,42$ & Orange colonies, flat \\
\hline 12 & Bacillus subterraneus & TSA & 37 & Transparent, irregular colonies \\
\hline 13 & Staphylococcus sciuri & TSA, NA, MA & 37 & Yellow, circular \\
\hline 14 & Micrococcus luteus & NA with $\mathrm{NaCl}$, MA & 37 & Light yellow, regular circular colony \\
\hline 15 & Bacillus megaterium & NA without and with $\mathrm{NaCl}$ & 32 & Foamy white colonies, irregular \\
\hline 16 & Jeotgalicoccus haukii & MA, NA with $\mathrm{NaCl}$ & 37 & Round, smooth, circular, white \\
\hline 17 & Bacillus cereus & MA, LB, NA & $27-32$ & $\begin{array}{l}\text { Irregular, opaque, white cream, little } \\
\text { fuzzy appearance }\end{array}$ \\
\hline 18 & Brevibacillus parabrevis & Trypticase soy agar, MA & $32-37$ & Pale yellow, circular \\
\hline 19 & Bacillus vallismortis & NA, MA & $27-32$ & Opaque, smooth circular \\
\hline 20 & Psychrobacter pulmonis & MA & 37 & White and opaque \\
\hline 21 & Bacillus licheniformis & MA, LB, NA & $27-42$ & $\begin{array}{l}\text { Opaque, hair-like outgrowths, whitish, colonies } \\
\text { round to irregular }\end{array}$ \\
\hline 22 & Paenibacillus silvae & MA, NA & 32 & Shiny, smooth, beige color, irregular \\
\hline 23 & Exiguobacterium mexicanum & MA & 37 & Orange, circular \\
\hline 24 & Bacillus jeotgali & $\mathrm{MA}, \mathrm{NA} 2 \% \mathrm{NaCl}$ & 32 & $\begin{array}{l}\text { Smooth and flat, irregular colony, cream yellow to } \\
\text { light yellow }\end{array}$ \\
\hline 25 & Bacillus boroniphilus & $\mathrm{MA}, \mathrm{NA}, \mathrm{LB} 2 \% \mathrm{NaCl}$ & & Opaqe, smooth surface \\
\hline 26 & Bacillus halasaccharovorans & MA & 32 & Circular, smooth, creamy \\
\hline 27 & Bacillus flexus & $10 \% \mathrm{NaCl}, 2 \% \mathrm{NaCl}, \mathrm{MA} \mathrm{lb}$ & 32 & Creamish white, smooth and opaque \\
\hline 28 & Bacillus velezensis & Tryptic soy agar (TSA or tryptic soy broth (TSB) & 27 & Creamish white, irregular \\
\hline 29 & Bacillus albus & LB medium with and without $\mathrm{NaCl}$ NA MA & 32 & White regular \\
\hline 30 & Bacillus tequilensis & TSA, MA & 37 & Round, smooth, yellowish in colour \\
\hline 31 & Bacillus amyloliquefaciens & MA & 37 & Irregular, raised, white mucous, filled and sticky \\
\hline
\end{tabular}

The number of bacterial colonies obtained from the carapace was higher than compared to other sources. The sampling source provided a difference since the bacterial colonies isolated from different samples were different. A maximum of colonies were 
isolated from HV crab carapace and sediment from its habitat (Figure 2). Additionally, the bacterial species characterized from the crab carapace $(n=11)$ and sediments were able to adapt to temperatures ranging at least between 27 and $42{ }^{\circ} \mathrm{C}$. From the ventral side of crabs, the number of obtained colonies was fewer, and the optimum temperature at which bacterial species could grow was between $32{ }^{\circ} \mathrm{C}$ and $37^{\circ} \mathrm{C}$.

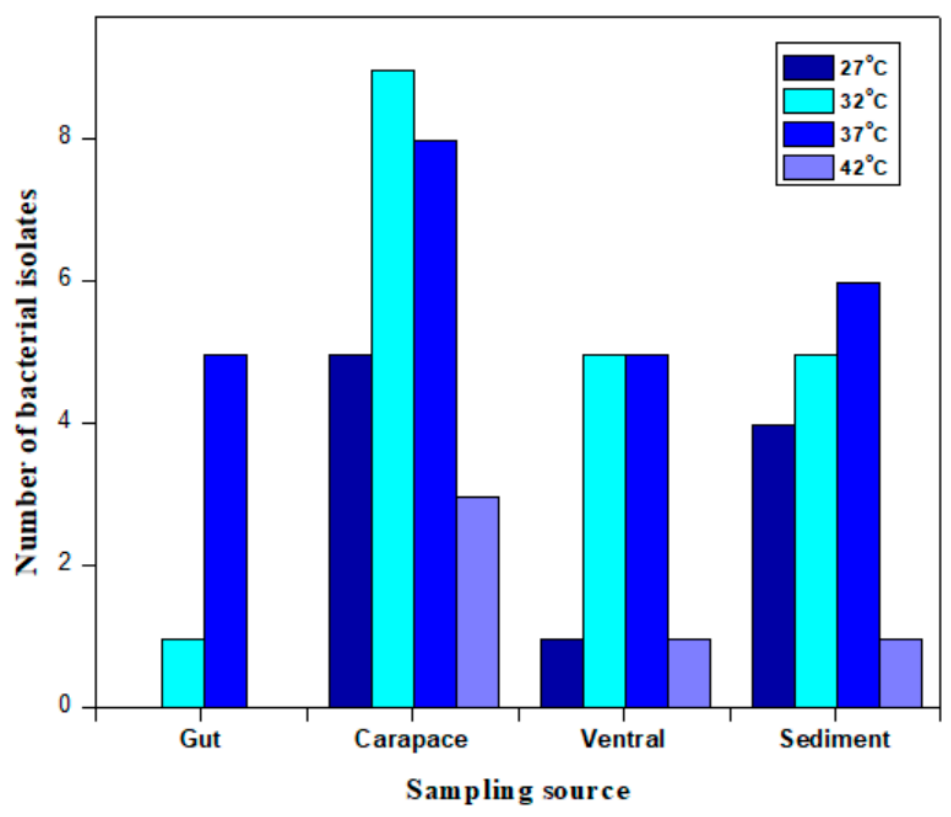

Figure 2. Bacterial diversity according to 16S RNA from different sediment and biogenic crab substrates.

\subsection{Products from Marine Isolates}

Thermophilic bacteria associated with hydrothermal vents are promising sources for research and commercial applications. In our study, 29 bacterial strains were isolated and cultivated from shallow-water marine hydrothermal vents around Kueishantao for the screening of protease activity. The protease assay was performed with and without $\mathrm{ZnSO}_{4}$ (Figure 3). Different concentrations of this metal ion were studied for its effect on protease activity (Table 3). The results demonstrate that Bacillus licheniformis, Bacillus amyloliquefaciens, Bacillus aquimaris and Micrococcus luteus hydrolyze the protein. The zone of lysis was observed for these isolates. In the presence of $\mathrm{ZnSO}_{4}$, the activity was concentration dependent. With low concentrations of $\mathrm{ZnSO}_{4}$, the protease activity was high, whereas protease activity was inhibited in the presence of high concentrations of $\mathrm{ZnSO}_{4}$ (Figure S1).

The strain producing the highest activity was identified as Bacillus cereus. The gene for protease was amplified from Bacillus cereus, cloned and expressed in Escherichia coli BL21 cells. The protein sequence retrieved from mass spectrometry analysis showed sequence similarity to that of the subtilisin-like serine protease protein, belonging to the family of S8 peptidases with a molecular weight of about $38 \mathrm{kDa}$ and a 38 aa signal peptide region. SLSP-k is a monomeric protein that is active over wide temperature $\left(40-80^{\circ} \mathrm{C}\right)$ and $\mathrm{pH}(7-11)$ ranges, showing maximal hydrolytic activity at $\mathrm{pH} 11$ and at a temperature of $50{ }^{\circ} \mathrm{C}$. The proteolytic activity was further elevated by $\mathrm{Co}^{2+}, \mathrm{Ca}^{2+}$, and $\mathrm{Mn}^{2+}, \mathrm{DTT}$, and inhibited by $\mathrm{Cu}^{2+}, \mathrm{Cd}^{2+}, \mathrm{Fe}^{2+}$, PMSF, and EDTA. SLSP-k was observed to be stable in non-anionic and anionic solvents and detergents. This protein shows keratinolytic degradation of chicken feathers. Hence, the protein is suitable for research applications, industrial product making and waste management [4].

A novel thermostable exopolysaccharide (EPS-B3-15) isolated from the thermophilic marine Bacillus licheniformis (B3-15) composed of glucose and mannose was recently reported as a beneficial compound with applications in bio- and nanotechnology, material sciences and pharmacology since it showed thermostability at high temperatures [37]. Although several bacterial xylanases were studied, only few could successfully be ex- 
tracted from marine-associated micro-organisms. Khandeparker et al. (2011) [38] isolated Bacillus subtilis cho40 and characterized a novel halotolerant xylanase from Chorao Island near Goa, India. This could be used for bioethanol production from marine seaweeds. The extracellular xylanase was produced by solid-state fermentation (SSF) with wheat bran as a carbon source. The optimal temperature was $60^{\circ} \mathrm{C}$, and the optimal $\mathrm{pH}$ was reported as 6.0. Xyn 40 was also reported as halophilic and showed maximum activity at $0.5 \mathrm{M} \mathrm{NaCl}$. The cloned xylanase gene, $x y n 40$, was $645 \mathrm{bp}$ long and coded for 215 amino acids with a molecular size of $22.9 \mathrm{kDa}$.
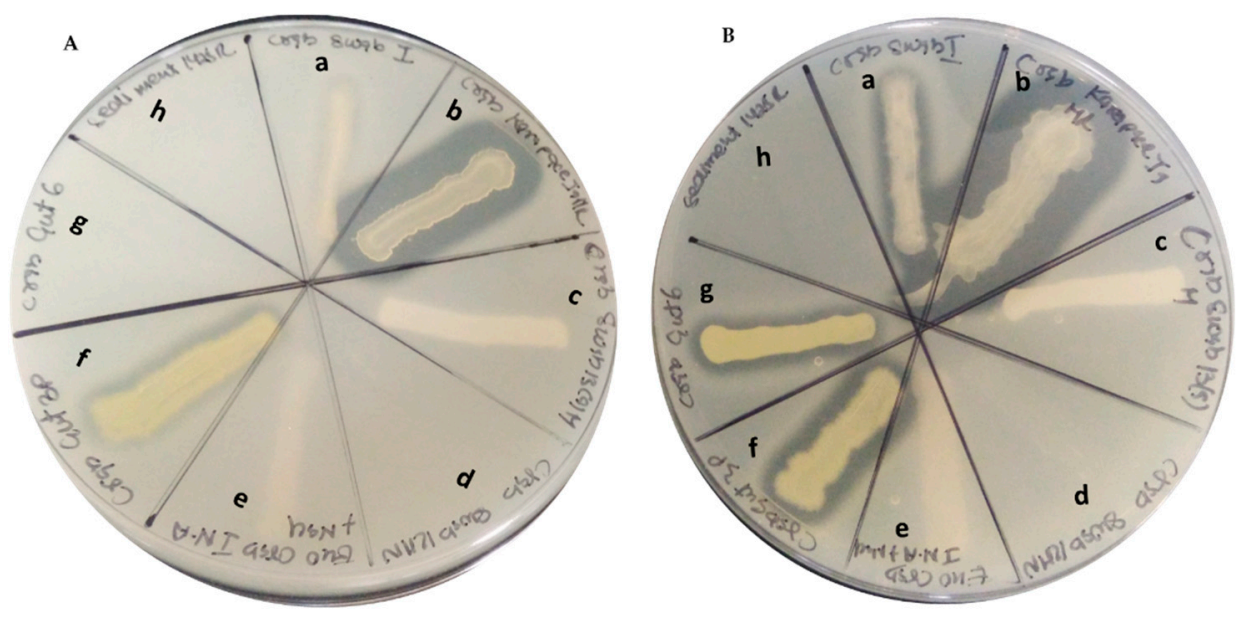

Figure 3. Protease assay. (A). In the presence of $500 \mu \mathrm{M} \mathrm{ZnSO}_{4}$. (B). Protease assay lacking $\mathrm{ZnSO}_{4}$. (a. Bacillus licheniformis, b. Bacillus amyloliquefaciens, c. Staphylococcus haemolyticus, d. Bacillus jeotgali, e. Bacillus firmus, f. Bacillus aquimaris, g. Micrococcus luteus, h. Bacillus subterraneus).

Table 3. Bacterial protease assay using skim milk in the presence of different concentrations of $\mathrm{ZnSO}_{4}$ (+: zone of inhibition is present; -: zone of inhibition is not present).

\begin{tabular}{ccccccc}
\hline \multirow{2}{*}{ S. No. } & \multirow{2}{*}{ Bacterial Strain } & \multicolumn{5}{c}{ Protease Assay in the Presence of $\mathbf{Z n S O}_{\mathbf{4}}$} \\
\cline { 3 - 6 } & & $\mathbf{5 0} \mathbf{\mu M}$ & $\mathbf{1 0 0} \boldsymbol{\mu M}$ & $\mathbf{5 0 0} \boldsymbol{\mu} \mathbf{M}$ & $\mathbf{1} \mathbf{~ m M}$ & $\mathbf{1 0} \mathbf{~ m M}$ \\
\hline 1 & Bacillus amyloliquefaciens & + & + & + & + & - \\
2 & Bacillus aquimaris & + & + & + & + & - \\
3 & Micrococcus luteus & + & + & - & - & - \\
4 & Bacillus jeotgali & - & - & - & - & - \\
5 & Bacillus firmus & - & - & - & - & - \\
\hline
\end{tabular}

Shofiyah et al. [39] extracted $\alpha$-amylase from Bacillus megaterium NL3, which was symbiotic with a cnidarian from Lake Kakaban, India. Shofiyah et al. [39] cloned the $\alpha$-amylase-encoding gene BmaN2 and expressed it in E. coli (DE3). This $\alpha$-amylase exhibited the highest activity at a temperature of $60^{\circ} \mathrm{C}$ and a $\mathrm{pH}$ of 6 . Its specific activity was calculated as $28.7 \mathrm{U} \mathrm{mg}^{-1}$. The enzyme activity was highly upregulated by $\mathrm{Ca}^{2+}$ and decreased in the presence of EDTA. BmaN2 also showed high catalytic activity on soluble starch with $k_{\text {cat }} / K_{\mathrm{M}}$ values of $14.1 \mathrm{~mL} \mathrm{mg}^{-1} \mathrm{~s}^{-1}$. Although the most preferred substrate with maximum hydrolytic activity by BmaN2 was granular wheat, BmaN2 can also hydrolyze raw starch, such as that of potato, sago, wheat, canna, corn, rice and cassava. An L-Asparaginase-producing bacterium, Bacillus velezensis, was isolated from marine sediments by Mostafa et al. [40]. L-Asparaginase free from glutaminase activity is required for medical applications; however, it also shows severe side effects. The purified enzyme was $39.7 \mathrm{KDa}$, as predicted by SDS, and it was efficiently active at $\mathrm{pH} 7.5$ and a temperature of $37^{\circ} \mathrm{C}$. The enzyme was studied for its anticancer properties in breast adenocarcinoma cell lines, and the results showed significant activity towards MDA-MB-231 cells with $\mathrm{IC}_{50}$ values of $12.6 \pm 1.2 \mu \mathrm{g} / \mathrm{mL}$ as compared to MCF-7 cells with $\mathrm{IC}_{50}$ values of $17.3 \pm 2.8 \mu \mathrm{g} / \mathrm{mL}$. 
Hamiche et al. [41] isolated Bacillus amyloliquefaciens (S13) from the phaeophycean macroalga Zonaria tournefortii. This bacterium produced extracellular moderately elastolytic and keratinolytic enzymes. The study suggested that the present enzymes were monomers, designated as KERZT-A of $28 \mathrm{kDa}$ and KERZT-B 47 of $\mathrm{kDa}$. The $\mathrm{NH}_{2}$-terminal amino acid showed high sequence homology with keratinases from Bacillus. Whereas KERZT-A showed maximal activity at $50{ }^{\circ} \mathrm{C}$ and $\mathrm{pH} 6.5$, KERZT-B showed highest activity at $60{ }^{\circ} \mathrm{C}$ and $\mathrm{pH}$ 8. Both enzymes were completely inhibited by PMSF (phenylmethanesulfonyl fluoride) and DFP (diiodopropyl fluorophosphate), indicating that they belong to the serine keratinase family. Additionally, the keratinase KERZT-A displayed a higher level of specificity towards substrate hydrolysis. Moreover, the catalytic efficiency was higher than that of KERUS from the Brevibacillus brevis strain US575, NUE 12 MG (commercial enzyme) and KERZT-B, an unhairing keratinase. Thus, the enzyme is of interest for medicinal applications as well as for the cosmetic and the leather industries.

In the search of substitutes for synthetic plastics, Mohandas et al. [42] screened, isolated and identified polyhydroxylalkanoates (PHAs) produced by bacteria isolated from marine water samples. A potent isolate of the moderately halophilic Bacillus cereus (MCCB 281) produced PHA co-polymers with glycerol as the main carbon source under optimized processing parameters involving a central composite design for increased PHA fermenter production. It showed a 1.5-fold higher PHA yield. PHA nanoparticles with an approximate size of $179 \mathrm{~nm}$ were created for medical purposes, and biocompatibility testing was carried out with L929 mouse fibroblast cell lines. Al Farraj et al. [43] enhanced the fibrinolytic enzyme (32 $\mathrm{kDa}$ ) yield from a marine Bacillus flexus by 3.5-fold using a central composite design standardized culture medium with a high enzyme yield (4711 $\pm 29.3 \mathrm{U} / \mathrm{g}$ of substrate). The fibrinolytic protein was expressed to its maximum at $50^{\circ} \mathrm{C}$ and a pH of 8 .

For the decontamination of organic pollutants, 19 bacterial isolates secreting extracellular enzymes were examined for their solvent tolerance by Trivedi et al. [44]. Bacillus aquimaris produced a cellulase with optimal activity at $\mathrm{pH} 11$ and at $45^{\circ} \mathrm{C}$. The enzyme was functionally stable and showed activity even at higher temperatures $\left(75^{\circ} \mathrm{C}\right)$ and at $\mathrm{pH} 12$. Enzyme activity in the presence of different metals was highest with $\mathrm{Co}^{+2}$ followed by $\mathrm{Fe}^{+2}$ and $\mathrm{NaOCl}_{2}$. In the presence of $\mathrm{CuSO}_{4}$, the activity was high as compared to $\mathrm{KCl}$ and $\mathrm{NaCl}$. The enzyme stability reported with the addition of solvents was highest in benzene $(122 \%)$, followed by methanol ( $85 \%)$, acetone $(75 \%)$ and toluene $(73 \%)$, and lowest with heptane $(42 \%)$. The activity of the enzyme was further enhanced when the protein was pre-incubated in ionic solvents such as 1-ethyl-3-methylimidazolium methane sulfonate and 1-ethyl-3-methylimidazolium bromide by $155 \%$ and $150 \%$, respectively.

One of the HPLC fractions of a biosurfactant was extracted from the marine Bacillus circulans by Das et al. [45], showing maximum surface tension-reducing properties and pronounced antibacterial action (MIC, MBC) against a group of Gram-positive and Grampositive and -negative bacterial pathogens and a few multidrug-resistant (MDR) pathogenic but non-hemolytic clinical bacteria. It was also reported that only one of the HPLC fractions showed antimicrobial efficacy and was non-hemolytic from crude biosurfactants [45].

He et al. [46] used preparative high-speed counter-current chromatography (HSCCC) to study the two macrolactin antibiotics from the marine bacterium Bacillus amyloliquefaciens. Previously, several reports showed that bioactive secondary metabolites can be obtained from sponge-associated bacteria. Kiran et al. [47] isolated 56 bacteria from the marine sponge Callyspongia diffusa and analyzed them for their activity against the MDR Staphylococcus aureus strain. The $16 \mathrm{~S}$ rRNA sequence and phylogenetic analysis identified the bacteria as Bacillus tequilensis showing antimicrobial activity. The isolate MSI45 was proven to produce the novel antibacterial compound pyrrolo [1,2-a] pyrazine-1,4-dione, hexahydro. This compound showed significant inhibition against multidrug-resistant Staphylococcus aureus with an MBC of $20 \pm 0.072 \mathrm{mg} \mathrm{L}^{-1}$ and an MIC of $15 \pm 0.172 \mathrm{mg} \mathrm{L}^{-1}$. The compound showed high antioxidant activity and was non-hemolytic. Saggese et al. [48] stated that the marine strain Bacillus pumilus (SF214) produced a protein compound with antibacterial activity. The small molecule of $3 \mathrm{kDa}$ exhibited activity against Staphylococcus 
aureus and the other larger molecule of $10 \mathrm{kDa}$ was active against the pathogen Listeria monocytogenes. A mass spectrometry analysis classified the small molecule as pumilacidin, a non-ribosomally synthesized biosurfactant that is active against Staphylococcus. Nisha et al. [49] characterized exopolysaccharides (EPS) produced by the marine bacterium Micrococcus luteus isolated from a ship hull at Cochin port, India. An EPS-associated compound from $M$. luteus was isolated and characterized, and the results showed antibacterial and antifungal activities against pathogens. An in vitro assay for cytotoxic activity of the pigment indicated antibacterial and antifungal activity. Furthermore, UVA rays' potential to absorb the pigment makes it unstable when applied in sunscreens.

\subsection{The Identification of Differences in Bacterial Colony Occurrence from the Sampling Source}

The bacteria restricted to the gut of the crab Xenograpsus testudinatus were Kocuria subflava, Paenibacillus silvae, Bacillus tequilensis and Micrococcus luteus; those restricted to sediments were Bacillus subterraneus, Brevibacillus parabrevis, Bacillus marisflavis, Bacillus velezensis, Jeotgalicoccus huakuii and Bacillus megaterium; those restricted to the ventral crab plate were Staphylococcus sciuri, Bacillus flexus, Bacillus halosaccharovorans, Bacillus jeotgali, Bacillus licheniformis, Bacillus amyloliquefaciens and Staphylococcus haemolyticus; and those from the carapace (=dorsal plate) were Bacillus firmus, Bacillus safensis, Bacillus iocasae, Bacillus aquimaris, Bacillus marisflavis, Bacillus vallismortis, Exiguobacterium mexicanum and Psychrobacter pulmonis. The species common to the gut and sediment were Bacillus ginseng and Bacillus aryabhattai. The bacteria found both in the sediments and on the carapace were Exiguobacterium aurantiacum, Bacillus cereus and Bacillus albus. Bacillus aerius was isolated from both the ventral plate and the carapace (Figure 4).

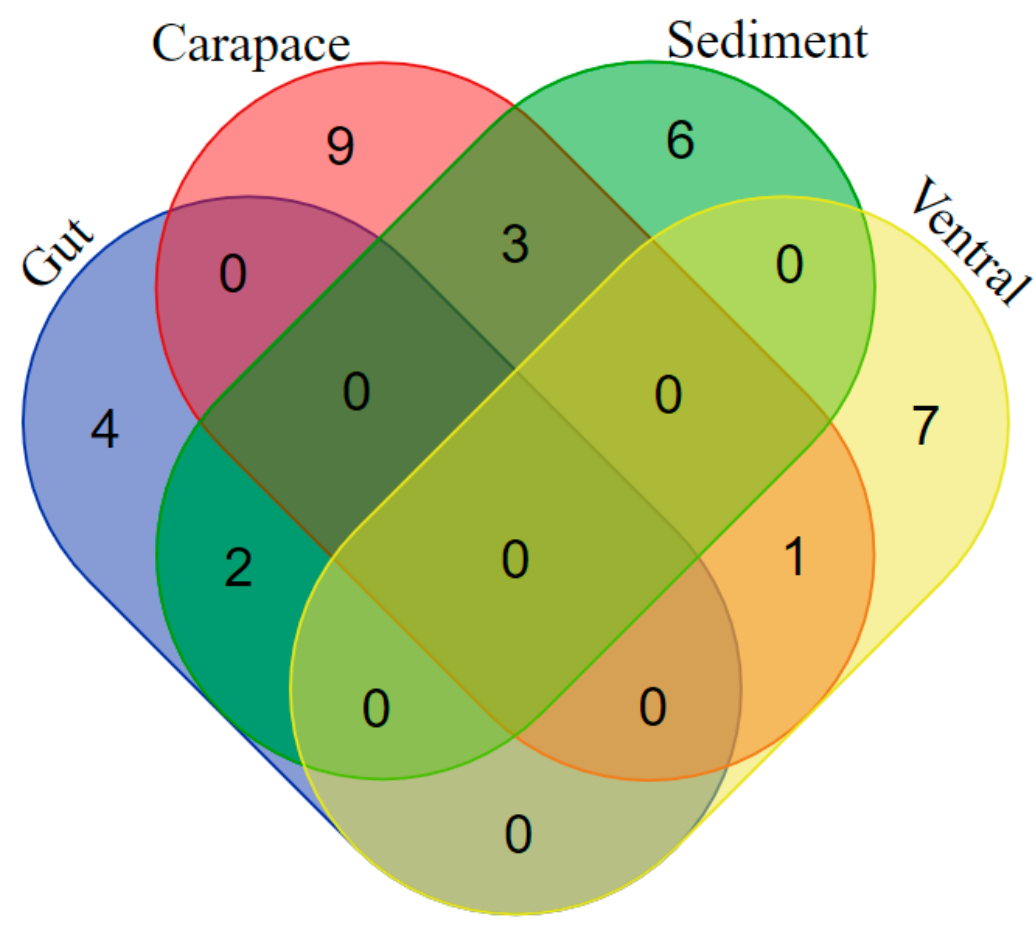

Figure 4. Venn diagram depicting the species commonly found at the sampling source, including unique species. Subset 1: Bacillus aerius; Subset 2: Bacillus ginseng and Bacillus aryabhattai; Subset 3: Exiguobacterium aurantiacum, Bacillus cereus and Bacillus albus; Subset 4: Kocuria subflava, Paenibacillus silvae, Bacillus tequilensis and Micrococcus luteus; Subset 6: Bacillus subterraneus, Brevibacillus parabrevis, Bacillus marisflavis, Bacillus velezensis, Jeotgalicoccus huakuii and Bacillus megaterium; Subset 7: Staphylococcus sciuri, Bacillus flexus, Bacillus halosaccharovorans, Bacillus jeotgali, Bacillus licheniformis, Bacillus amyloliquefaciens and Staphylococcus haemolyticus; Subset 9: Bacillus firmus, Bacillus safensis, Bacillus iocasae, Bacillus aquimaris, Bacillus marisflavis, Bacillus vallismortis, Exiguobacterium mexicanum and Psychrobacter pulmonis. 
The reports of the bacterial diversity of the blue crab Callinectes sapidus from the Gulf of Thermaikos, North Aegean Sea, Greece, showed that it comprised Proteobacteria and Tenericutes, followed by Actinobacteria and Firmicutes. Firmicutes were found in abundance in crabs when stored at $4{ }^{\circ} \mathrm{C}$. Additionally, species of Psychrobacter spp. were isolated from crab samples [50]. In another study, culturable microbiota from Chionoecetes opilio, Chionoecetes sp. and C. japonicus were isolated using six different media. The phylogenetic relation obtained by $16 \mathrm{~S}$ rRNA gene sequences showed that the culture belonged to Acinetobacter, Pseudomonas and Stenotrophomonas. In the crab Chionoecetes opilio, Bacillus spp. were localized in the heart and in the gill, as in Chionoecetes opilio and Chionoecetes japonicus. Bacillus spp. was isolated from carapace and from Chionoecetes sp.; Bacillus spp. were identified from carapace juices and the heart [51]. An analysis of the bacterial diversity of the crab Callinectes sapidus revealed that the predominant bacterial genus present in the hemolymph was Vibrio, followed by Bacillus, Acinetobacter and Flavobacterium [52,53].

\section{Materials and Methods}

\subsection{Sample Collection and Colony Isolation}

Crab (Xenograpsus testudinatus) and sediment samples from Kueishantao hydrothermal vents were aseptically collected and immediately processed after bringing them to the laboratory. Different media were prepared to isolate a maximum number of individual bacterial species. The media used were Nutrient agar, Luria Bertani agar, Tryptic soy agar, TCBS media, Zobell marine media, brain heart infusion agar, sea water complete and Casamino acid sea water. All the media were prepared in either sea water or distilled water. From the crab samples, swabs were prepared from the crab dorsal, ventral portion and gut and were spread on all the respective media plates. The crab samples were homogenized and serially diluted up to $10^{5}$. The sediment samples were serially diluted to $10^{5}$, and $100 \mu \mathrm{L}$ from each dilution was spread on all the different media plates. The plates were incubated at $27^{\circ} \mathrm{C}, 32^{\circ} \mathrm{C}, 37^{\circ} \mathrm{C}$ and $42^{\circ} \mathrm{C}$.

\subsection{DNA Sequencing and Phylogenetic Analysis}

A single colony was inoculated in the respective medium, which showed the optimal growth of the bacteria at the optimal temperature and was kept in a shaking incubator at $150 \mathrm{rpm}$. Genomic DNA was isolated applying a GeneJET Genomic DNA Purification Kit (Thermo Scientific, Waltham, MA, USA). The PCR reaction with Taq buffer (1X), dNTP $(0.2 \mathrm{mM})$, reverse and forward primers (1 $\mu \mathrm{M}$ each), 50-100 ng template DNA, Taq DNA polymerase $(1.25 \mathrm{U})$ (New England biolabs) and bi-distilled water to a final volume of $25 \mu \mathrm{L}$ was set. Universal primers, 27F (5'-AGAGTTTGATCCTGGCTCAG-3') and 1492R (5'-GGTTACCTTGTTACGACTT-3') were used to amplify the $16 \mathrm{~S}$ rRNA sequence. The PCR reaction conditions were set with initial denaturation of $94{ }^{\circ} \mathrm{C}$ for $5 \mathrm{~min}, 35$ cycles of $95{ }^{\circ} \mathrm{C}$ $(1 \mathrm{~min}), 55{ }^{\circ} \mathrm{C}(1 \mathrm{~min}), 72{ }^{\circ} \mathrm{C}(1: 40 \mathrm{~min})$ and final elongation at $72{ }^{\circ} \mathrm{C}(10 \mathrm{~min})$, and the amplified PCR product was run in agarose gel and purified by a GeneJet PCR purification kit (Thermo Scientific, Waltham, MA, USA). The eluted DNA samples were sent for 16S rRNA sequencing.

\subsection{Phylogenetic Tree}

For 16S rRNA sequencing, both forward (27F) and reverse (1492R) primers were used. Sequences were obtained by Sanger sequencing. Forward and reverse sequences were analyzed and assembled using MEGAX [54]. The full-length sequences were used for nucleotide sequence analysis to find highly similar species [55]. Phylogenetic trees were built using MEGAX [54]; sequence alignment using Muscle tool was performed; and tree estimates were retrieved using the maximum likelihood test (100 bootstraps).

\subsection{Protease Assay}

A protease assay was performed using skim milk powder. Skim milk agar plates were prepared using 1\% skim milk powder. The bacterial colonies were inoculated in broth 
and allowed to grow overnight. The overnight culture was streaked on pre-prepared agar plates and incubated at $37^{\circ} \mathrm{C}$ again overnight. A zone of lysis was observed. A study was performed with and without the presence of $\mathrm{ZnSO}_{4}$. Different concentrations of $\mathrm{ZnSO}_{4}$ were used to study its effect on protease activity.

\section{Conclusions}

Using different cultivation methods, a maximum number of colonies were isolated, and distinct colonies were classically identified by different morphology or color. The present study is the first report of microbial diversity derived from laboratory cultures that were classified by sequencing. The sequencing results revealed that most of the bacterial species belonged to the phylum Firmicutes. The classified bacteria mostly belonged to the genus Bacillus. The number of bacterial colonies obtained from the carapace was higher than compared to other sources. Bacterial colonies differed according to sample origin. The highest number of colonies was isolated from HV crab carapace and sediments. This study was carried out to derive bacteria from extreme conditions with the ability to tolerate a wide range of $\mathrm{pH}$, high temperatures, varying pressure and nutrient availability. This provides the expectation of extracting unique metabolites that protect organisms from extreme physicochemical factors. Additionally, this can be used to study the pathways adopted by such extremophiles to adapt to toxic compounds and physical conditions in such extreme environments. Microbial adaptations at the genomic, proteomic and metabolomic level are expected to be of substantial applied interest for biotechnology, medical and industrial applications.

Supplementary Materials: The following are available online at https:/ /www.mdpi.com/article/10.3 390/md19120681/s1, Figure S1. Protease assay in the presence of $50 \mu \mathrm{M}$ ZnSO4. B. Protease assay with $100 \mu \mathrm{M}$ ZnSO4. C. Protease assay with $1 \mathrm{mM}$ ZnSO4. D. Protease assay with $10 \mathrm{mM}$ ZnSO4 (a. Bacillus licheniformis, b. Bacillus amyloliquefaciens, c. Staphylococcus haemolyticus, d. Bacillus jeotgali, e. Bacillus firmus, f. Bacillus aquimaris, g. Micrococcus luteus, h. Bacillus subterraneus).

Author Contributions: Conceptualization, experimentation, and writing original draft: R.G.; project administration, funding acquisition: H.-U.D. and J.-S.H.; writing-review and editing: A.J.R., H.-U.D.; methodology: A.J.R., R.G.; experimentation, sampling: R.G. All authors have read and agreed to the published version of the manuscript.

Funding: The authors acknowledge the support from KMU-TC108A02. A grant from MOST to Tan Han Shih (Hans-Uwe Dahms) is gratefully acknowledged (MOST 107-2621-M-037-001, MOST 1082621-M-037-001 and MOST 109-2621-M-037-001). This work was supported partially by the Research Center for Environmental Medicine, Kaohsiung Medical University, Kaohsiung, Taiwan, from The Featured Areas Research Center Program within the framework of the Higher Education Sprout Project by the Ministry of Education (MOE) in Taiwan and by the Kaohsiung Medical University Research Center Grant (KMU-TC108A01). Financial support from the Ministry of Science and Technology of Taiwan (Grant Nos. MOST 107-2621-M-019-001, MOST 108-2621-M-019-003, MOST 109-2621-M-019-002 and MOST 110-2621-M-019-001) and Center of Excellence for Ocean Engineering (Grant No. 109J13801-51, 110J13801-51) was provided to Jiang-Shiou Hwang.

Acknowledgments: We thank our students in the lab for their continuous support.

Conflicts of Interest: The authors declare no conflict of interest.

\section{References}

1. Rampelotto, P. Extremophiles and Extreme Environments. Life 2013, 3, 482-485. [CrossRef] [PubMed]

2. Dahms, H.-U.; Schizas, N.V.; James, R.A.; Wang, L.; Hwang, J.-S. Marine hydrothermal vents as templates for global change scenarios. Hydrobiologia 2018, 818, 1-10. [CrossRef]

3. Dahms, H.U.; Peterson, T.R.; Baveye, P.C. Editorial: Innovative Approaches to Learning in Environmental Science. Front. Environ. Sci. 2020, 8, 121. [CrossRef]

4. Gurunathan, R.; Huang, B.; Ponnusamy, V.K.; Hwang, J.-S.; Dahms, H.-U. Novel recombinant keratin degrading subtilisin like serine alkaline protease from Bacillus cereus isolated from marine hydrothermal vent crabs. Sci. Rep. 2021, 11, 12007. [CrossRef]

5. Brock, T.D. Life at High Temperatures. Science 1985, 230, 132-138. [CrossRef]

6. Brock, T.D. The road to yellowstone and beyond. Annu. Rev. Microbiol. 1995, 49, 1-29. [CrossRef] [PubMed] 
7. Dinh, K.V.; Doan, K.L.U.; Doan, N.X.; Pham, H.Q.; Le, T.H.O.; Le, M.-H.; Vu, M.T.T.; Dahms, H.-U.; Truong, K.N. Parental exposures increase the vulnerability of copepod offspring to copper and a simulated marine heatwave. Environ. Pollut. 2021, 287, 117603. [CrossRef] [PubMed]

8. Stetter, K.O. History of discovery of the first hyperthermophiles. Extremophiles 2006, 10, 357-362. [CrossRef] [PubMed]

9. Kuo, F.W. Priminary Investigation of the Hydrothermal Activities off Kueishantao Island; National Sun Yat-Sen University: Kaohsiung, Taiwan, 2001. (In Chinese)

10. Chen, Y.-G.; Wu, W.-S.; Chen, C.-H.; Liu, T.-K. A date for volcanic eruption inferred from a siltstone xenolith. Quat. Sci. Rev. 2001, 20, 869-873. [CrossRef]

11. Tarasov, V.G.; Gebruk, A.V.; Mironov, A.N.; Moskalev, L.I. Deep-sea and shallow-water hydrothermal vent communities: Two different phenomena? Chem. Geol. 2005, 224, 5-39. [CrossRef]

12. Liu, C.H.; Wang, X.M.; Zeng, Z.G.; Yin, X.B.; Chen, C.T.A.; Zhang, S.W. Origin of the hydrothermal fluid of the shallow sea near Kueishantao Island. Mar. Sci. 2010, 34, 61-68. (In Chinese)

13. Franco, P.; Dahms, H.-U.; Hwang, J.-S. Pelagic tunicates at shallow hydrothermal vents of Kueishantao. PLoS ONE 2019, 14, e0225387. [CrossRef] [PubMed]

14. Chen, C.A.; Wang, B.; Huang, J.; Lou, J.; Kuo, F.; Tu, Y.; Tsai, H. Investigation into extremely acidic hydrothermal fluids off Kueishan Tao, Taiwan, China. Acta Oceanol. Sin. 2005, 24, 125-133.

15. Chen, C.-T.A.; Zeng, Z.; Kuo, F.-W.; Yang, T.F.; Wang, B.-J.; Tu, Y.-Y. Tide-influenced acidic hydrothermal system offshore NE Taiwan. Chem. Geol. 2005, 224, 69-81. [CrossRef]

16. Chen, X.-G.; Lyu, S.-S.; Garbe-Schönberg, D.; Lebrato, M.; Li, X.; Zhang, H.-Y.; Zhang, P.-P.; Chen, C.-T.A.; Ye, Y. Heavy metals from Kueishantao shallow-sea hydrothermal vents, offshore northeast Taiwan. J. Mar. Syst. 2018, 180, 211-219. [CrossRef]

17. Lebrato, M.; Wang, Y.V.; Tseng, L.-C.; Achterberg, E.P.; Chen, X.-G.; Molinero, J.-C.; Bremer, K.; Westernströer, U.; Söding, E.; Dahms, H.-U.; et al. Earthquake and typhoon trigger unprecedented transient shifts in shallow hydrothermal vent biogeochemistry. Sci. Rep. 2019, 9, 16926. [CrossRef]

18. Jeng, M.-S.; Ng, N.K.; Ng, P.K.L. Feeding behaviour: Hydrothermal vent crabs feast on sea "snow". Nature 2004, $432,969$. [CrossRef] [PubMed]

19. Pang, K.-L.; Guo, S.-Y.; Chen, I.-A.; Burgaud, G.; Luo, Z.-H.; Dahms, H.U.; Hwang, J.-S.; Lin, Y.-L.; Huang, J.-S.; Ho, T.-W.; et al. Insights into fungal diversity of a shallow-water hydrothermal vent field at Kueishan Island, Taiwan by culture-based and metabarcoding analyses. PLoS ONE 2019, 14, e0226616. [CrossRef]

20. Hough, D.W.; Danson, M.J. Extremozymes. Curr. Opin. Chem. Biol. 1999, 3, 39-46. [CrossRef]

21. Hencyia, S.; Vengateshwarana, T.D.; Gokul, M.S.; Rajasabapathy, R.; Vignesh, S.; Krishnan Muthukumar, K.; Kaviarasan, M.; Veeramania, T.; Dahms, H.-U.; James, R.A. Solar saltern bacteria as an effective inhibitor of diabetic foot drug resistant pathogens. Curr. Microbiol. 2020, 77, 3711-3723.

22. Pang, K.-L.; Chiang, M.W.-L.; Guo, S.-Y.; Shih, C.-Y.; Dahms, H.U.; Hwang, J.-S.; Cha, H.-J. Growth study under combined effects of temperature, $\mathrm{pH}$ and salinity and transcriptome analysis revealed adaptations of Aspergillus terreus NTOU4989 to the extreme conditions at Kueishan Island Hydrothermal Vent Field, Taiwan. PLoS ONE 2020, 15, e0233621. [CrossRef]

23. Zhu, D.; Adebisi, W.A.; Ahmad, F.; Sethupathy, S.; Danso, B.; Sun, J. Recent Development of Extremophilic Bacteria and Their Application in Biorefinery. Front. Bioeng. Biotechnol. 2020, 8. [CrossRef]

24. Hong, J.F.; Ouddane, B.; Hwang, J.-S.; Dahms, H.-U. In silico assessment of health risks mediated by marine cyanobacteria. Biocell 2021, 45, 65-77. [CrossRef]

25. Huang, H.; Jia, Q.Y.; Jing, W.; Dahms, H.-U.; Wang, L. Screening strains for microbial biosorption technology of cadmium. Chemosphere 2020, 251, 126428. [CrossRef] [PubMed]

26. Xu, H.S.; Roberts, N.; Singleton, F.L.; Attwell, R.W.; Grimes, D.J.; Colwell, R.R. Survival and viability of nonculturable Escherichia coli and Vibrio cholerae in the estuarine and marine environments. Microb. Ecol. 1982, 8, 313-323. [CrossRef] [PubMed]

27. Simu, K.; Holmfeldt, K.; Zweifel, U.L.; Hagström, A. Culturability and Coexistence of Colony-Forming and Single-Cell Marine Bacterioplankton. Appl. Environ. Microbiol. 2005, 71, 4793-4800. [CrossRef] [PubMed]

28. Cerf, O.; Carpentier, B.; Sanders, P. Tests for determining in-use concentrations of antibiotics and disinfectants are based on entirely different concepts: "Resistance" has different meanings. Int. J. Food Microbiol. 2010, 136, 247-254. [CrossRef] [PubMed]

29. Pasotti, L.; Zucca, S.; Lupotto, M.; Cusella De Angelis, M.; Magni, P. Characterization of a synthetic bacterial self-destruction device for programmed cell death and for recombinant proteins release. J. Biol. Eng. 2011, 5, 8. [CrossRef] [PubMed]

30. Prieto-Barajas, C.M.; Alfaro-Cuevas, R.; Valencia-Cantero, E.; Santoyo, G. Effect of seasonality and physicochemical parameters on bacterial communities in two hot spring microbial mats from Araró, Mexico. Rev. Mex. Biodivers. 2017, 88, 616-624. [CrossRef]

31. Cui, H.; Su, X.; Chen, F.; Holland, M.; Yang, S.; Liang, J.; Su, P.; Dong, H.; Hou, W. Microbial diversity of two cold seep systems in gas hydrate-bearing sediments in the South China Sea. Mar. Environ. Res. 2019, 144, 230-239. [CrossRef]

32. Kumar, R.; Mishra, A.; Jha, B. Bacterial community structure and functional diversity in subsurface seawater from the western coastal ecosystem of the Arabian Sea, India. Gene 2019, 701, 55-64. [CrossRef] [PubMed]

33. Meyer-Dombard, D.R.; Amend, J.P.; Osburn, M.R. Microbial diversity and potential for arsenic and iron biogeochemical cycling at an arsenic rich, shallow-sea hydrothermal vent (Tutum Bay, Papua New Guinea). Chem. Geol. 2013, 348, 37-47. [CrossRef]

34. Shinde, V.L.; Meena, R.M.; Shenoy, B.D. Phylogenetic characterization of culturable bacteria and fungi associated with tarballs from Betul beach, Goa, India. Mar. Pollut. Bull. 2018, 128, 593-600. [CrossRef] [PubMed] 
35. Vipindas, P.V.; Mujeeb, R.K.M.; Jabir, T.; Thasneem, T.R.; Mohamed Hatha, A.A. Diversity of sediment bacterial communities in the South Eastern Arabian Sea. Reg. Stud. Mar. Sci. 2020, 35, 101153. [CrossRef]

36. Grossart, H.-P.; Schlingloff, A.; Bernhard, M.; Simon, M.; Brinkhoff, T. Antagonistic activity of bacteria isolated from organic aggregates of the German Wadden Sea. FEMS Microbiol. Ecol. 2004, 47, 387-396. [CrossRef]

37. Caccamo, M.T.; Gugliandolo, C.; Zammuto, V.; Magazù, S. Thermal properties of an exopolysaccharide produced by a marine thermotolerant Bacillus licheniformis by ATR-FTIR spectroscopy. Int. J. Biol. Macromol. 2020, 145, 77-83. [CrossRef] [PubMed]

38. Khandeparker, R.; Verma, P.; Deobagkar, D. A novel halotolerant xylanase from marine isolate Bacillus subtilis cho40: Gene cloning and sequencing. New Biotechnol. 2011, 28, 814-821. [CrossRef]

39. Shofiyah, S.S.; Yuliani, D.; Widya, N.; Sarian, F.D.; Puspasari, F.; Radjasa, O.K.; Ihsanawati; Natalia, D. Isolation, expression, and characterization of raw starch degrading $\alpha$-amylase from a marine lake Bacillus megaterium NL3. Heliyon 2020, 6, e05796. [CrossRef] [PubMed]

40. Mostafa, Y.; Alrumman, S.; Alamri, S.; Hashem, M.; Al-izran, K.; Alfaifi, M.; Elbehairi, S.E.; Taha, T. Enhanced production of glutaminase-free l-asparaginase by marine Bacillus velezensis and cytotoxic activity against breast cancer cell lines. Electron. J. Biotechnol. 2019, 42, 6-15. [CrossRef]

41. Hamiche, S.; Mechri, S.; Khelouia, L.; Annane, R.; El Hattab, M.; Badis, A.; Jaouadi, B. Purification and biochemical characterization of two keratinases from Bacillus amyloliquefaciens S13 isolated from marine brown alga Zonaria tournefortii with potential keratinbiodegradation and hide-unhairing activities. Int. J. Biol. Macromol. 2019, 122, 758-769. [CrossRef] [PubMed]

42. Mohandas, S.P.; Balan, L.; Jayanath, G.; Anoop, B.S.; Philip, R.; Cubelio, S.S.; Bright Singh, I.S. Biosynthesis and characterization of polyhydroxyalkanoate from marine Bacillus cereus MCCB 281 utilizing glycerol as carbon source. Int. J. Biol. Macromol. 2018, 119, 380-392. [CrossRef] [PubMed]

43. Al Farraj, D.A.; Kumar, T.S.J.; Vijayaraghavan, P.; Elshikh, M.S.; Alkufeidy, R.M.; Alkubaisi, N.A.; Alshammari, M.K. Enhanced production, purification and biochemical characterization of therapeutic potential fibrinolytic enzyme from a new Bacillus flexus from marine environment. J. King Saud Univ.-Sci. 2020, 32, 3174-3180. [CrossRef]

44. Trivedi, N.; Gupta, V.; Kumar, M.; Kumari, P.; Reddy, C.R.K.; Jha, B. Solvent tolerant marine bacterium Bacillus aquimaris secreting organic solvent stable alkaline cellulase. Chemosphere 2011, 83, 706-712. [CrossRef] [PubMed]

45. Das, P.; Mukherjee, S.; Sen, R. Antimicrobial potential of a lipopeptide biosurfactant derived from a marine Bacillus circulans. J. Appl. Microbiol. 2008, 104, 1675-1684. [CrossRef] [PubMed]

46. He, S.; Wang, H.; Yan, X.; Zhu, P.; Chen, J.; Yang, R. Preparative isolation and purification of macrolactin antibiotics from marine bacterium Bacillus amyloliquefaciens using high-speed counter-current chromatography in stepwise elution mode. J. Chromatogr. A 2013, 1272, 15-19. [CrossRef] [PubMed]

47. Kiran, G.S.; Priyadharsini, S.; Sajayan, A.; Ravindran, A.; Selvin, J. An antibiotic agent pyrrolo [1,2-a]pyrazine-1,4-dione, hexahydro isolated from a marine bacterium Bacillus tequilensis MSI45 effectively controls multi-drug resistant Staphylococcus aureus. RSC Adv. 2018, 8, 17837-17846. [CrossRef]

48. Saggese, A.; Culurciello, R.; Casillo, A.; Corsaro, M.; Ricca, E.; Baccigalupi, L. A Marine Isolate of Bacillus pumilus secretes a Pumilacidin Active against Staphylococcus aureus. Mar. Drugs 2018, 16, 180. [CrossRef]

49. Nisha, P.; John, N.; Mamatha, C.; Thomas, M. Characterization of bioactive compound produced by microfouling actinobacteria (Micrococcus luteus) isolated from the ship hull in Arabian Sea, Cochin. Kerala. Mater. Today Proc. 2020, 25, 257-264. [CrossRef]

50. Parlapani, F.F.; Michailidou, S.; Anagnostopoulos, D.A.; Koromilas, S.; Kios, K.; Pasentsis, K.; Psomopoulos, F.; Argiriou, A.; Haroutounian, S.A.; Boziaris, I.S. Bacterial communities and potential spoilage markers of whole blue crab (Callinectes sapidus) stored under commercial simulated conditions. Food Microbiol. 2019, 82, 325-333. [CrossRef] [PubMed]

51. Kim, M.; Kwon, T.-H.; Jung, S.-M.; Cho, S.-H.; Jin, S.Y.; Park, N.-H.; Kim, C.-G.; Kim, J.-S. Antibiotic Resistance of Bacteria Isolated from the Internal Organs of Edible Snow Crabs. PLoS ONE 2013, 8, e70887. [CrossRef]

52. Colwell, R.R.; Wicks, T.C.; Tubiash, H.S. A comparative study of the bacterial flora of the hemolymph of Callinectes sapidus. Mar. Fish. Rev. 1975, 37, 29-33.

53. Sizemore, R.K.; Colwell, R.R.; Tubiash, H.S.; Lovelace, T.E. Bacterial Flora of the Hemolymph of the Blue Crab, Callinectes sapidus: Numerical Taxonomy. Appl. Microbiol. 1975, 29, 393-399. [CrossRef] [PubMed]

54. Kumar, S.; Stecher, G.; Li, M.; Knyaz, C.; Tamura, K. MEGA X: Molecular Evolutionary Genetics Analysis across Computing Platforms. Mol. Biol. Evol. 2018, 35, 1547-1549. [CrossRef] [PubMed]

55. Altschul, S.F.; Gish, W.; Miller, W.; Myers, E.W.; Lipman, D.J. Basic local alignment search tool. J. Mol. Biol. 1990, 215 , 403-410. [CrossRef] 